\title{
Mechanisms of $\mathrm{P}^{*}$ Reduction in the Eastern Tropical South Pacific
}

\author{
Judith Meyer ${ }^{1 *}$, Carolin R. Löscher ${ }^{2}$, Gaute Lavik ${ }^{3}$ and Ulf Riebesell ${ }^{1,4}$ \\ ${ }^{1}$ Geomar Helmholtz Centre for Ocean Research Kiel, Kiel, Germany, ${ }^{2}$ Nordic Center for Earth Evolution, Department of \\ Biology, University of Southern Denmark, Odense, Denmark, ${ }^{3}$ Max-Planck-Institute for Marine Microbiology, Bremen, \\ Germany, ${ }^{4}$ Department of Biology, Christian-Albrechts-University Kiel, Kiel, Germany
}

\section{OPEN ACCESS}

Edited by:

Osvaldo Ulloa,

University of Concepción, Chile

Reviewed by:

Eric A. Webb

University of Southern California, USA

Matthew McGinness Mills,

Stanford University, USA

*Correspondence: Judith Meyer

jumeyer@geomar.de

Specialty section: This article was submitted to Marine Biogeochemistry, a section of the journal

Frontiers in Marine Science

Received: 23 February 2016 Accepted: 05 January 2017

Published: 19 January 2017

Citation:

Meyer J, Löscher CR, Lavik G and Riebesell U (2017) Mechanisms of P*

Reduction in the Eastern Tropical South Pacific. Front. Mar. Sci. 4:1. doi: 10.3389/fmars.2017.00001
Water masses influenced by oxygen minimum zones (OMZ) feature low inorganic nitrogen $(N)$ to phosphorus $(P)$ ratios. The surplus of $P$ over $N$ is thought to favor non-Redfield primary production by bloom-forming phytoplankton species. Additionally, excess phosphate $\left(P^{*}\right)$ is thought to provide a niche for nitrogen fixing organisms. In order to assess the effect of low inorganic nutrient ratios on the stoichiometry and composition of primary producers, biogeochemical measurements were carried out in 2012 during a research cruise in the eastern tropical South Pacific (ETSP). Based on pigment analyses, a succession of different phytoplankton functional groups was observed along onshore-offshore transects with diatoms dominating the productive upwelling region, and prymnesiophytes, cryptophytes, and Synechococcus prevailing in the oligotrophic open ocean. Although inorganic nutrient supply ratios were below Redfield proportions throughout the sampling area, the stoichiometry of particulate organic nitrogen to phosphorus (PON:POP) generally exceeded ratios of 16:1. Despite $P O N: P O P \geq 16$, high $P^{*}$-values in the surface layer $(0-50 \mathrm{~m})$ above the shelf rapidly decreased as water masses were advected offshore. There are three mechanisms which can explain these observations: (1) non-Redfield primary production, where the excess phosphorus in the biomass is directly released as dissolved organic phosphorus (DOP), (2) non-Redfield primary production, which is masked by a particulate organic matter pool mainly consisting of P-depleted detrital biomass, and/or (3) Redfield primary production combined with dinitrogen $\left(\mathrm{N}_{2}\right)$ fixation. Our observations suggest that the three processes occur simultaneously in the study area; quantifying the relative importance of each of these mechanisms needs further investigation. Therefore, it remains uncertain whether the ETSP is a net sink for bioavailable $\mathrm{N}$ or whether the $\mathrm{N}$-deficit in this area is replenished locally.

Keywords: Peruvian upwelling, N:P ratio, excess phosphate $\left(\mathrm{P}^{*}\right)$, diazotrophs, phytoplankton, $\mathrm{N}_{2}$ fixation

\section{INTRODUCTION}

The Humboldt Current system is one of four major eastern boundary upwelling systems (EBUS). It is characterized by intense, year-round upwelling of nutrient loaded waters that facilitate intense biological production in the euphotic zone (Pennington et al., 2006). Closely linked to the productive surface layer is an oxygen minimum zone (OMZ), where nitrogen $(\mathrm{N})$ loss processes (denitrification and anammox) diminish the amount of bioavailable N (Goering, 1968; Hamersley et al., 2007). Hypoxia and anoxia induced phosphorus (P) release from the sediment (Ingall and Jahnke, 1994; Noffke et al., 2012; Lomnitz et al., 2016) results in a surplus of $\mathrm{P}$ over $\mathrm{N}$ in the 
water column (referred to as $\mathrm{P}^{*}$, after Deutsch et al., 2007). Thus, upwelled water masses feature N:P stoichiometries below the Redfield ratio, which describes the globally integrated ratio of macronutrients in seawater and in organic matter (C:N:P = 106:16:1, Redfield, 1958). The deficit of nitrate over phosphate is thought to create an environment beneficial for autotrophic dinitrogen $\left(\mathrm{N}_{2}\right)$ fixers (Deutsch et al., 2007), suggesting a close spatial coupling of $\mathrm{N}$ loss and $\mathrm{N}_{2}$ fixation. The presumption is, that phytoplankton in the highly productive shelf area consume $\mathrm{N}$ and $\mathrm{P}$ in Redfield proportions, while not altering $\mathrm{P}^{*}$ as waters are transported offshore. It has been further proposed that high supplies of dissolved organic phosphorus (DOP), which are produced under excess P (Ruttenberg and Dyhrman, 2012; Meyer et al., 2016), might additionally stimulate growth of $\mathrm{N}_{2}$ fixing diazotrophs (Franz et al., 2012b; Somes and Oschlies, 2015), as these organisms are known to use DOP as $\mathrm{P}$ source either exclusively or in addition to $\mathrm{P}$ (Dyhrman et al., 2006; Sohm and Capone, 2006). But despite low N:P ratios accompanied by replete amounts of $\mathrm{P}^{*}$ and DOP in upwelled waters, no evidence for a significant abundance of diazotrophic cyanobacteria or autotrophic $\mathrm{N}_{2}$ fixation has yet been found in the Peruvian or Chilean upwelling systems (Franz et al., 2012a,b; Dekaezemacker et al., 2013). However, N:P ratios in the surface layer are apparently restored to Redfield proportions and $P^{*}$-values are reduced as water masses are advected offshore (Franz et al., 2012b). Non-Redfield utilization of inorganic nutrients has been suggested as an alternative pathway for the consumption of $\mathrm{P}^{*}$ (Arrigo, 2005; Mills and Arrigo, 2010; Franz et al., 2012b). Different N:P utilization ratios in phytoplankton have been confirmed by laboratory and field data, which vary with growth rate, taxonomy and nutrient availability (e.g., Geider and La Roche, 2002; Quigg et al., 2003; Moore et al., 2008). Fast growing phytoplankton, for example, often utilize nutrients at low ratios, as they invest in P-rich ribosomes required for fast growth (Klausmeier et al., 2004b; Arrigo, 2005). The deficiency of $\mathrm{N}$ over P in upwelled waters provides favorable conditions for these organisms, which could reduce the presence of excess phosphate via non-Redfield utilization. This mechanism of $\mathrm{P}^{*}$ reduction was also used to explain the apparent absence of diazotrophic $\mathrm{N}_{2}$ fixation in the Humboldt upwelling system (Mills and Arrigo, 2010; Franz et al., 2012b). This hypothesis was challenged by the recent discovery of heterotrophic $\mathrm{N}_{2}$ fixers in OMZ influenced water masses off Peru and Chile (Bonnet et al., 2013; Loescher et al., 2014; Fernandez et al., 2015), which may play a role in reducing the $\mathrm{N}$ deficit particularly of water masses below the oxycline (Loescher et al., 2014).

In this study we analyzed nutrient dynamics and stoichiometries of dissolved and particulate organic matter during an expedition in the eastern tropical South Pacific (ETNA) in order to elucidate the mechanisms responsible for $\mathrm{P}^{*}$ consumption and N:P restoration to Redfield proportions in the surface ocean layer off Peru. By means of high performance liquid chromatography (HPLC), a method to determine phytoplankton pigments, we evaluated how non-Redfield nutrient stoichiometries affect the spatial distribution and community composition of diazotrophic and non-diazotrophic phytoplankton. To provide an estimate of the diazotrophic activity, direct $\mathrm{N}_{2}$ fixation measurements were undertaken.

\section{MATERIALS AND METHODS}

Samples were collected during research expedition M93 on RV Meteor from February 07th until March 09th 2013 in the frame of the Collaborative Research Centre (SFB) 754: Climate-Biogeochemistry Interactions in the Tropical Ocean. In total, 47 stations were sampled between $12^{\circ} \mathrm{S}$ and $14^{\circ} \mathrm{S}$ (Figure 1A). In this study, we will focus on the three northern transects of our working area. At each station, samples were collected from 3 to 12 discrete depths with either a CTD mounted on a rosette with 24 bottles (10 L) or a pump-CTD system (Strady et al., 2008).

Nutrient concentrations $\left[\mathrm{NO}_{3}^{-}, \mathrm{PO}_{4}^{3-}\right.$ and $\left.\mathrm{Si}(\mathrm{OH})_{4}\right]$ were determined with a QuAAtro autoanalyzer (Seal Analytical) directly onboard following Grasshoff et al. (1999). P* was calculated from $\mathrm{NO}_{3}^{-}$and $\mathrm{PO}_{4}^{3-}$ measurements after Deutsch et al. (2007) as $\mathrm{P}^{*}=\mathrm{PO}_{4}^{3-}-\mathrm{NO}_{3}^{-} / \mathrm{r}_{16: 1}$, where $\mathrm{r}_{16: 1}$ refers to the globally integrated ratio of nitrate and phosphate in seawater. Seawater samples for particulate organic carbon (POC), nitrogen $(\mathrm{PON})$, phosphorus (POP), chlorophyll $a(\mathrm{Chl} a)$, and HPLC

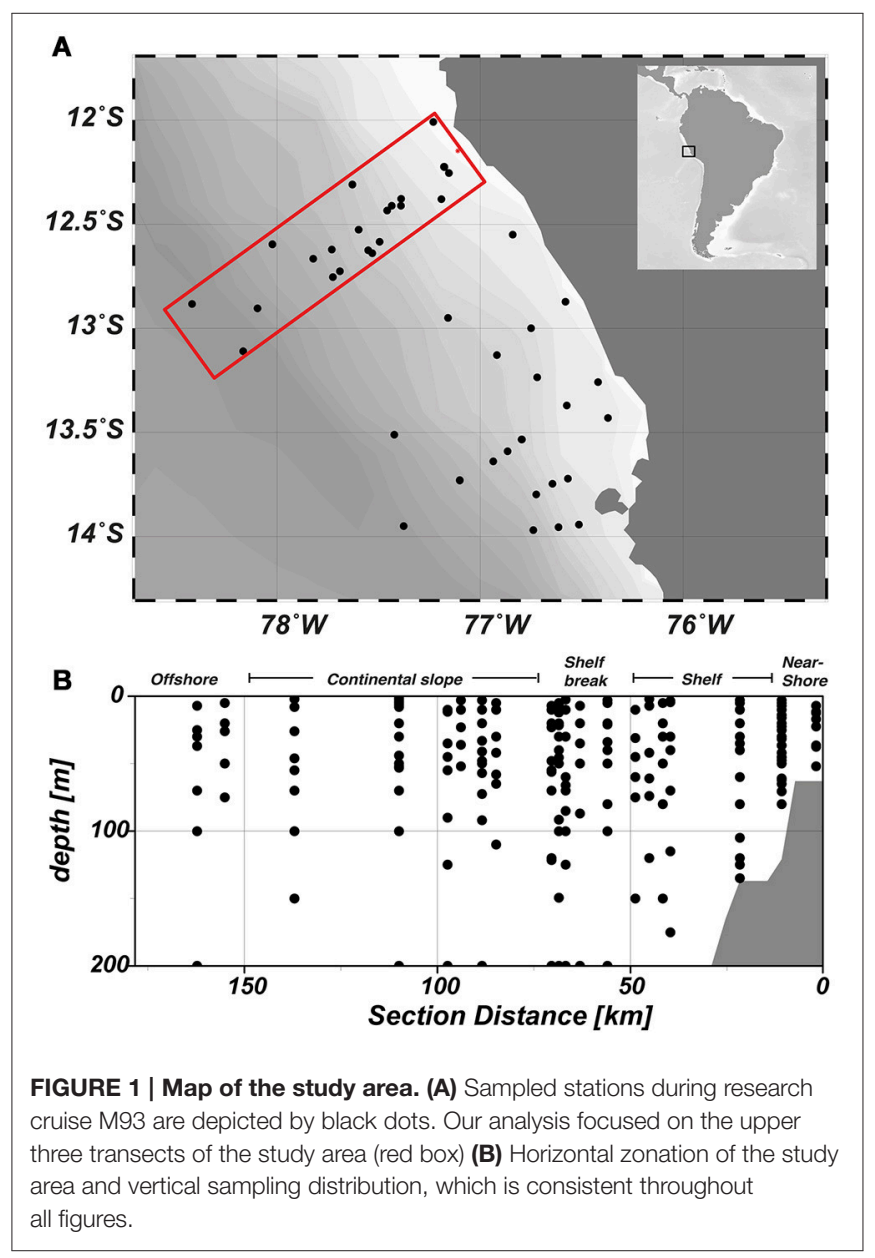


analysis were filtered through pre-combusted $\left(5 \mathrm{~h}\right.$ at $\left.450^{\circ} \mathrm{C}\right)$ $25 \mathrm{~mm}$ Whatman GF/F filters $(0.7 \mu \mathrm{m}$ pore size, pressure < 200 mbar). For biogenic silica (BSi) analysis, water samples were filtered through $25 \mathrm{~mm}$ cellulose acetate filters $(0.65 \mu \mathrm{m}$ pore size, $<200$ mbar pressure). Filters for POC, PON, POP, BSi, and HPLC analysis were immediately stored frozen $\left(-20^{\circ} \mathrm{C}\right.$ for POC, PON, POP, BSi; $-80^{\circ} \mathrm{C}$ for HPLC) until later analysis.

POC and PON analyses were performed using an elemental analyzer (Euro EA, EuroVector). Prior to analysis, POC filters were placed in an exsiccator containing fuming $\mathrm{HCl}$ for $12 \mathrm{~h}$ in order to remove particulate inorganic carbon and then dried for $12 \mathrm{~h}$ at $60^{\circ} \mathrm{C}$. POP was determined photometrically (Hansen and Koroleff, 1999) after the treatment with Oxisolv ${ }^{\circledR}$ (Merck) in order to oxidize all particulate organic phosphorus to orthophosphate. For DOP analysis, $60 \mathrm{~mL}$ of sample was filtered through pre-combusted $\left(450^{\circ} \mathrm{C}, 5 \mathrm{~h}\right) 25 \mathrm{~mm}$ Whatman $\mathrm{GF} / \mathrm{F}$ filters $(0.7 \mu \mathrm{m}$ pore size $)$ and stored frozen $\left(-20^{\circ} \mathrm{C}\right)$ in acid cleaned HDPE bottles. Prior to analysis, the filtrate was autoclaved with Oxisolv (Merck) for $30 \mathrm{~min}$. Oxidized organic phosphorus was measured spectrophotometrically as phosphate on a QuAAtro autoanalyzer (Seal Analytical; Hansen and Koroleff, 1999). DOP concentrations were then determined as the difference between total dissolved phosphorus and dissolved inorganic phosphate. BSi was converted to dissolved silicate while heating the filters in $0.1 \mathrm{~mol} \mathrm{~L}^{-1} \mathrm{NaOH}$ at $85^{\circ} \mathrm{C}$ for $2 \mathrm{~h} 15$ mins. The dissolved silicate was then determined spectrophotometrically (Hansen and Koroleff, 1999).

Chl a concentrations were determined directly onboard. After overnight extraction with $90 \%$ acetone, fluorescence was measured with a Turner Trilogy fluorometer, which was previously calibrated with a standardized solution (Anacystis nidulans, Walter CMP). Chl $a$ was calculated following Parsons et al. (1984).

While Chl $a$ is a proxy of phytoplankton biomass, certain accessory pigments (e.g., chlorophylls, carotenoids) are algaeclass specific (Trees et al., 2000). Thus, the relationship between accessory pigments to $\mathrm{Chl}$ a can be used as a measure for phytoplankton community composition (e.g., Gieskes et al., 1988; Wright, 1991; Mackey et al., 1998; Greisberger and Teubner, 2007). In order to extract phytoplankton pigments for HPLC analysis, 90\% acetone was added to the filters, which were then homogenized with glass beads and centrifuged for $10 \mathrm{~min}$ at $5000 \mathrm{rpm}$. The supernatants were filtered through $0.2 \mu \mathrm{m}$ Teflon filters to remove filter debris and the extracts were immediately stored at $-80^{\circ} \mathrm{C}$. Extracts were later analyzed for pigments via HPLC (Dionex UltiMate ${ }^{\circledR} 3000$ LC system equipped with an autosampler, a photodiode array and a fluorescence detector, Thermo Scientific), following Barlow et al. (1997). Pigments were identified through comparison with the retention times and spectral properties of standards (DHI Water \& Environment, Denmark). The relative contribution of phytoplankton groups to total Chl a was calculated using the CHEMTAX matrix factorization software (Mackey et al., 1996). We used an initial ratio matrix that was based on ratios developed by DiTullio et al. (2005) and Mackey et al. (1996) for the equatorial Pacific and Peruvian upwelling region. Slight modifications were made in order to account for the presence of the pigment aphanizophyll (Apha). This carotenoid has only been found in cyanobacteria to date (Hertzberg et al., 1971; Jeffrey et al., 2011) and is regarded a potential marker pigment for diazotrophs (Louda et al., 2015). However, Apha has also been detected in the non-diazotrophic freshwater species Microcystis aeruginosa (Hertzberg and Liaaen-Jensen, 1971), which suggests that the detection of Apha might not necessarily indicate the presence of diazotrophic cyanobacteria. Nevertheless, in the marine environment no non-diazotrophs are known to synthesize Apha (Hauss et al., 2012). Since the ratio of Apha to Chl $a$ in marine cyanobacteria is not given in the literature, an approximation based on cultur experiments was used (Schluter et al., 2004). Divinyl-chlorophyll $a$ (Div $a$ ) concentrations were directly used as in index for Prochlorococcus abundances. Hence, zeaxanthin (Zeax) attributed to Prochlorococcus had to be accounted for, since it needed to be excluded from the CHEMTAX calculations. For that, we first calculated the contribution of each algae class to Zeax and subtracted the Prochlorococcus Zeax from the initial Zeax concentrations. We further divided our data set into different bins for CHEMTAX calculations in order to account for different algae class compositions between surface/chlorophyll maximum, deep chlorophyll maximum and mesopelagic zone (see Table 1 for output matrices).

$\mathrm{N}_{2}$ fixation rates were determined from triplicate ${ }^{15} \mathrm{~N}-\mathrm{N}_{2}$ incubations, following the protocol by Mohr et al. (2010). Before incubation, a sample was taken and immediately filtered through a $25 \mathrm{~mm}$ Whatman GF/F filter to determine initial ${ }^{15} \mathrm{~N}$ levels at each depth. For $\mathrm{N}_{2}$ fixation measurements, triplicate $4.5 \mathrm{~L}$ acid-cleaned $(3 \% \mathrm{HCl})$ Nalgene bottles were filled with seawater from the CTD rosette at each station and depth. ${ }^{15} \mathrm{~N}-\mathrm{N}_{2}$ enriched seawater was prepared from the same water samples. For this, water was degassed and collected in a gas-tight, acidcleaned Tedlar ${ }^{\circledR}$ bag and amended with $1 \mathrm{~mL}$ of ${ }^{15} \mathrm{~N}-\mathrm{N}_{2}$ gas (98 atom $\%{ }^{15} \mathrm{~N}$, Cambridge Isotopes, Lot no.: I-16727) for every $100 \mathrm{~mL}$ of water sample. After complete dissolution of the added gas, a $100 \mathrm{~mL}$ aliquot of the enriched water was added to every incubation bottle without leaving any headspace. Water samples were incubated for $24 \mathrm{~h}$ in on-deck incubators, which were connected to a flow-through seawater system and were shaded with blue lagoon light foil to simulate light levels at the corresponding water depth. After $24 \mathrm{~h}$, samples were filtered onto pre-combusted $25 \mathrm{~mm}$ Whatman GF/F filters and stored frozen $\left(-20^{\circ} \mathrm{C}\right)$. Filters were later analyzed using mass spectrometry as previously described in Loescher et al. (2014). Unfortunately, several $\mathrm{N}_{2}$ fixation measurements had to be omitted, as samples for the initial ${ }^{15} \mathrm{~N}$ levels and/or samples for the labeling efficiency were lost.

\section{RESULTS}

\section{Hydrographical Setting}

In February/March 2012, sampling began close to the shore and progressed perpendicular to the coast, thereby crossing the continental shelf (width $\sim 60 \mathrm{~km}$ ), the shelf break at approximately $77.5^{\circ} \mathrm{W}$ and the Peru/Chile undercurrent over the continental slope (Figure 1B). Coastal upwelling of water from 50 to $100 \mathrm{~m}$ water depth occurred between $12^{\circ}$ and $14^{\circ} \mathrm{S}$, 
TABLE 1 | Pigment to chlorophyll a (Chl a) ratios of different algae classes calculated by CHEMTAX.

\begin{tabular}{|c|c|c|c|c|c|c|c|c|c|c|c|c|c|c|c|c|c|}
\hline Surface/Chl max bin & Chl a & Chl $b$ & C3 & C2 & Peri & 19-But & Fuco & Neox & Pras & Vio & 19-Hex & Allox & $\mathrm{DD}+\mathrm{DT}$ & Lutein & Zeax & Myxo & Apha \\
\hline Diatoms & 0.50 & 0 & 0 & 0.16 & 0 & 0 & 0.30 & 0 & 0 & 0 & 0 & 0 & 0.04 & 0 & 0 & 0 & 0 \\
\hline Dinoflagellates & 0.47 & 0 & 0 & 0.15 & 0.28 & 0 & 0 & 0 & 0 & 0 & 0 & 0 & 0.09 & 0 & 0 & 0 & 0 \\
\hline Prymnesiophytes & 0.36 & 0 & 0.13 & 0.08 & 0 & 0 & 0.13 & 0 & 0 & 0 & 0.22 & 0 & 0.07 & 0 & 0 & 0 & 0 \\
\hline Chrysophytes & 0.26 & 0 & 0.09 & 0.05 & 0 & 0.29 & 0.03 & 0 & 0 & 0 & 0.03 & 0 & 0.25 & 0 & 0 & 0 & 0 \\
\hline Chlorophytes & 0.48 & 0.10 & 0 & 0 & 0 & 0 & 0 & 0 & 0 & 0.05 & 0 & 0 & 0 & 0.34 & 0.03 & 0 & 0 \\
\hline Cryptophytes & 0.78 & 0 & 0 & 0.09 & 0 & 0 & 0 & 0 & 0 & 0 & 0 & 0.13 & 0 & 0 & 0 & 0 & 0 \\
\hline Prasinophytes & 0.41 & 0.39 & 0 & 0 & 0 & 0 & 0 & 0.04 & 0.10 & 0.04 & 0 & 0 & 0 & 0 & 0.01 & 0 & 0 \\
\hline Synechococcus & 0.71 & 0 & 0 & 0 & 0 & 0 & 0 & 0 & 0 & 0 & 0 & 0 & 0 & 0 & 0.29 & 0 & 0 \\
\hline Colonial cyanobacteria & 0.89 & 0 & 0 & 0 & 0 & 0 & 0 & 0 & & 0 & 0 & 0 & 0 & 0 & 0.09 & 0.02 & 0 \\
\hline Diazotrophic cyanobacteria & 0.75 & 0 & 0 & 0 & 0 & 0 & 0 & 0 & 0 & 0 & 0 & 0 & 0 & 0 & 0.01 & 0.13 & 0.11 \\
\hline \multicolumn{18}{|l|}{ 2nd Chl max bin } \\
\hline Diatoms & 0.50 & 0 & 0 & 0.16 & 0 & 0 & 0.30 & 0 & 0 & 0 & 0 & 0 & 0.04 & 0 & 0 & 0 & 0 \\
\hline Dinoflagellates & 0.47 & 0 & 0 & 0.15 & 0.28 & 0 & 0 & 0 & 0 & 0 & 0 & 0 & 0.09 & 0 & 0 & 0 & 0 \\
\hline Prymnesiophytes & 0.30 & 0 & 0.07 & 0.07 & 0 & 0 & 0.11 & 0 & 0 & 0 & 0.39 & 0 & 0.06 & 0 & 0 & 0 & 0 \\
\hline Chrysophytes & 0.26 & 0 & 0.09 & 0.05 & 0 & 0.29 & 0.03 & 0 & 0 & 0 & 0.03 & 0 & 0.25 & 0 & 0 & 0 & 0 \\
\hline Chlorophytes & 0.48 & 0.10 & 0 & 0 & 0 & 0 & 0 & 0 & 0 & 0.05 & 0 & 0 & 0 & 0.34 & 0.03 & 0 & 0 \\
\hline Cryptophytes & 0.78 & 0 & 0 & 0.09 & 0 & 0 & 0 & 0 & 0 & 0 & 0 & 0.13 & 0 & 0 & 0 & 0 & 0 \\
\hline Prasinophytes & 0.41 & 0.39 & 0 & 0 & 0 & 0 & 0 & 0.04 & 0.10 & 0.04 & 0 & 0 & 0 & 0 & 0.01 & 0 & 0 \\
\hline Synechococcus & 0.65 & 0 & 0 & 0 & 0 & 0 & 0 & 0 & 0 & 0 & 0 & 0 & 0 & 0 & 0.35 & 0 & 0 \\
\hline Colonial cyanobacteria & 0.89 & 0 & 0 & 0 & 0 & 0 & 0 & 0 & 0 & 0 & 0 & 0 & 0 & 0 & 0.09 & 0.02 & 0 \\
\hline Diazotrophic cyanobacteria & 0.82 & 0 & 0 & 0 & 0 & 0 & 0 & 0 & 0 & 0 & 0 & 0 & 0 & 0 & 0.01 & 0.05 & 0.12 \\
\hline \multicolumn{18}{|l|}{ Mesopelagic bin } \\
\hline Diatoms & 0.52 & 0 & 0 & 0.12 & 0 & 0 & 0.31 & 0 & 0 & 0 & 0 & 0 & 0.05 & 0 & 0 & 0 & 0 \\
\hline Dinophytes & 0.47 & 0 & 0 & 0.15 & 0.28 & 0 & 0 & 0 & 0 & 0 & 0 & 0 & 0.10 & 0 & 0 & 0 & 0 \\
\hline Prymnesiophytes & 0.33 & 0 & 0.08 & 0.07 & 0 & 0 & 0.12 & 0 & 0 & 0 & 0.33 & 0 & 0.06 & 0 & 0 & 0 & 0 \\
\hline Chrysophytes & 0.26 & 0 & 0.09 & 0.05 & 0 & 0.29 & 0.03 & 0 & 0 & 0 & 0.03 & 0 & 0.25 & 0 & 0 & 0 & 0 \\
\hline Chlorophytes & 0.48 & 0.10 & 0 & 0 & 0 & 0 & 0 & 0 & 0 & 0.05 & 0 & 0 & 0 & 0.34 & 0.03 & 0 & 0 \\
\hline Cryptophytes & 0.78 & 0 & 0 & 0.09 & 0 & 0 & 0 & 0 & 0 & 0 & 0 & 0.13 & 0 & 0 & 0 & 0 & 0 \\
\hline Prasinophytes & 0.41 & 0.39 & 0 & 0 & 0 & 0 & 0 & 0.04 & 0.10 & 0.04 & 0 & 0 & 0 & 0 & 0.01 & 0 & 0 \\
\hline Synechococcus & 0.65 & 0 & 0 & 0 & 0 & 0 & 0 & 0 & 0 & 0 & 0 & 0 & 0 & 0 & 0.35 & 0 & 0 \\
\hline Colonial cyanobacteria & 0.89 & 0 & 0 & 0 & 0 & 0 & 0 & 0 & 0 & 0 & 0 & 0 & 0 & 0 & 0.09 & 0.02 & 0 \\
\hline Diazotrophic cyanobacteria & 0.68 & 0 & 0 & 0 & 0 & 0 & 0 & 0 & 0 & 0 & 0 & 0 & 0 & 0 & 0.01 & 0.02 & 0.29 \\
\hline
\end{tabular}

Samples were divided into 3 different bins prior to analysis. Abbreviations: Chl b: chlorophyll b; C3: chlorophyll c 3 ; C2: chlorophyll c2; Peri: peridinin; 19-But: 19'-butanoyloxyfucoxanthin; Fuco: fucoxanthin; Neox: neoxanthin; Pras: prasinoxanthin; Vio: violaxanthin; 19-Hex: 19'-hexanoyloxyfucoxanthin; Allox: alloxanthin; DD + DT: diadinoxanthin and diatoxanthin; Zeax: zeaxanthin; Myxo: myxoxanthophyll; Apha: aphanizophyll.

with near surface temperatures of around $17^{\circ} \mathrm{C}$ on the shelf and around $23^{\circ} \mathrm{C}$ further offshore (Figure 2). Mean oxygen $\left(\mathrm{O}_{2}\right)$ concentrations at the surface were around $240 \mu \mathrm{mol} \mathrm{kg}^{-1}$ and decreased rapidly with depth. $\mathrm{O}_{2}$ concentrations $<1 \mu \mathrm{mol} \mathrm{kg}-1$ were already observed at around $30 \mathrm{~m}$ depth above the shelf, while the oxycline deepened further offshore and anoxic waters were encountered at depth around $80 \mathrm{~m}$ (Thomsen et al., 2016).

\section{Distribution of Dissolved Inorganic and Organic Nutrients}

Upwelled water masses featured high concentrations of nitrate, phosphate and silicate of around 20, 2.5, and $15 \mu \mathrm{mol} \mathrm{L}^{-1}$, respectively (Figures 3A-C). Nitrate concentrations were low near the shelf sediment $\left(0-3 \mu \mathrm{mol} \mathrm{L}^{-1}\right)$, at stations closest to the shore $\left(0-1 \mu \mathrm{mol} \mathrm{L} \mathrm{L}^{-1}\right)$ and in surface waters $(0-$ $\left.1 \mu \mathrm{mol} \mathrm{L}{ }^{-1}\right)$. Highest phosphate and silicate concentrations were observed right above the shelf $\left(3.4\right.$ and $30 \mu \mathrm{mol} \mathrm{L} \mathrm{L}^{-1}$, respectively) and decreased toward the surface and as waters were transported away from shore. Here, minimum concentrations of $0.3-0.6 \mu \mathrm{mol} \mathrm{L}^{-1}$ for phosphate and $0-1 \mu \mathrm{mol} \mathrm{L}^{-1}$ for silicate were measured. Throughout the study area, N:P ratios never reached Redfield proportions (Figure 3D). Maximum values of 12:1 were observed right below the surface layer between 20 and $50 \mathrm{~m}$, while lower values between 2-5:1 were measured in the upper $20 \mathrm{~m}$ of the water column. Extremely low values between 0 and 2 coincided either with the complete absence of nitrate (i.e., above the sediment) or both nitrate and phosphate (i.e., in the surface layer at offshore stations). A surplus of phosphate over nitrate was measured in the whole water column, corresponding to the observations of low N:P values in the study area (Figure 3E). Maximum $\mathrm{P}^{*}$ concentrations were measured at near shore stations above the shelf sediment $\left(3 \mu \mathrm{mol} \mathrm{L}^{-1}\right)$, 
while lowest concentrations of $0.5 \mu \mathrm{mol} \mathrm{L} \mathrm{L}^{-1}$ were found in the upper $40 \mathrm{~m}$ of the water column. DOP concentrations in the study area were elevated in the surface layer (Figure 3F). Particularly above the shelf, maximum concentrations of up to $0.6 \mu \mathrm{mol} \mathrm{L}^{-1}$ were measured down to $50 \mathrm{~m}$ water depth. Accompanied by a shoaling of the nutricline, DOP values decreased to $0-0.2 \mu \mathrm{mol} \mathrm{L}{ }^{-1}$ as water masses were transported offshore.

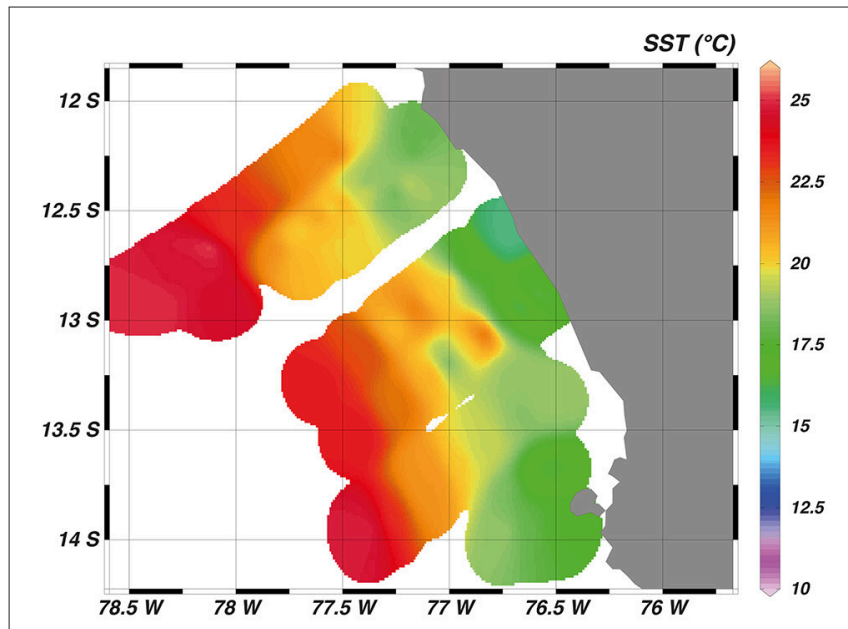

FIGURE 2 | Measured sea surface temperature (SST) in ${ }^{\circ} \mathrm{C}$ in the eastern tropical South Pacific.

\section{Particulate Organic Matter Dynamics}

Elevated concentrations of PON (4-8 $\left.\mu \mathrm{mol} \mathrm{L}^{-1}\right)$ were measured in the upper $20-30 \mathrm{~m}$ (Figure 4A), with maximum values $\left(\sim 8 \mu \mathrm{mol} \mathrm{L}^{-1}\right)$ observed close to the surface at near shore and shelf stations. Similar to PON, high POP concentrations (0.3-0.6 $\left.\mu \mathrm{mol} \mathrm{L}{ }^{-1}\right)$ were observed in the upper water column (Figure 4B). Despite very low inorganic N:P ratios in the whole study area, PON:POP ratios above Redfield proportions ( $24: 1)$ prevailed (Figure 4C). Only at few stations values of 16:1 or slightly lower were encountered. In general, PON:POP ratios of 16-20:1 were observed at near shore and shelf stations throughout the water column and between 0 and $20 \mathrm{~m}$ water depth further offshore. At stations above the continental slope (50-100 km distance to shore) we observed high PON:POP values of $\sim 40: 1$ at depths between 40 and $200 \mathrm{~m}$.

\section{Phytoplankton Biomass and Composition}

Chlorophyll $a$ (Chl $a)$ concentrations reached highest values $\left(\sim 6 \mu \mathrm{g} \mathrm{L}^{-1}\right)$ in the upper $20 \mathrm{~m}$ of the near shore and shelf stations $(<50 \mathrm{~km}$ distance to shore; Figure 4D), associated with a community dominated by diatoms (Figure 5A). These findings are in agreement with the distribution of biogenic silica (Figure S1), a mineral synthesized by diatoms and therefore a good indicator for the abundance of this algae class. In addition to diatoms, cryptophytes were present at the near shore stations and high concentrations of prymnesiophytes and prasinophytes were found above the shelf (Figures 5B-D). Elevated Chl $a$ concentrations $\left.(\sim 3 \mu \mathrm{mol} \mathrm{L})^{-1}\right)$ were also observed in the upper
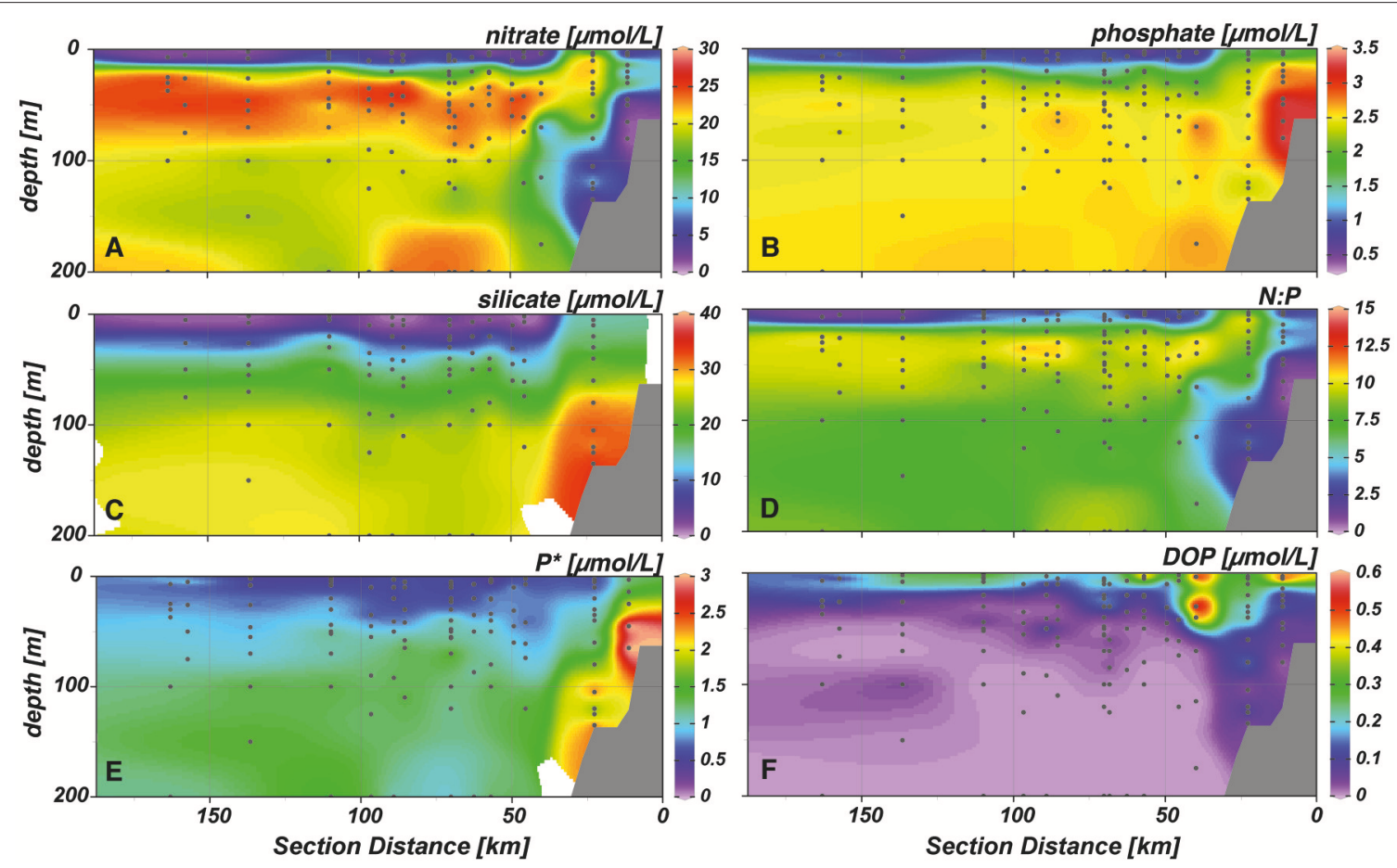

FIGURE 3 | Cross-shelf transects with interpolated concentrations of (A) nitrate, (B) phosphate, (C) silicate, (D) nitrate to phosphate ratio (N:P), (E) excess phosphate $\left(\mathrm{P}^{\star}\right)$, and $\mathbf{( F )}$ dissolved organic phosphorus (DOP). 

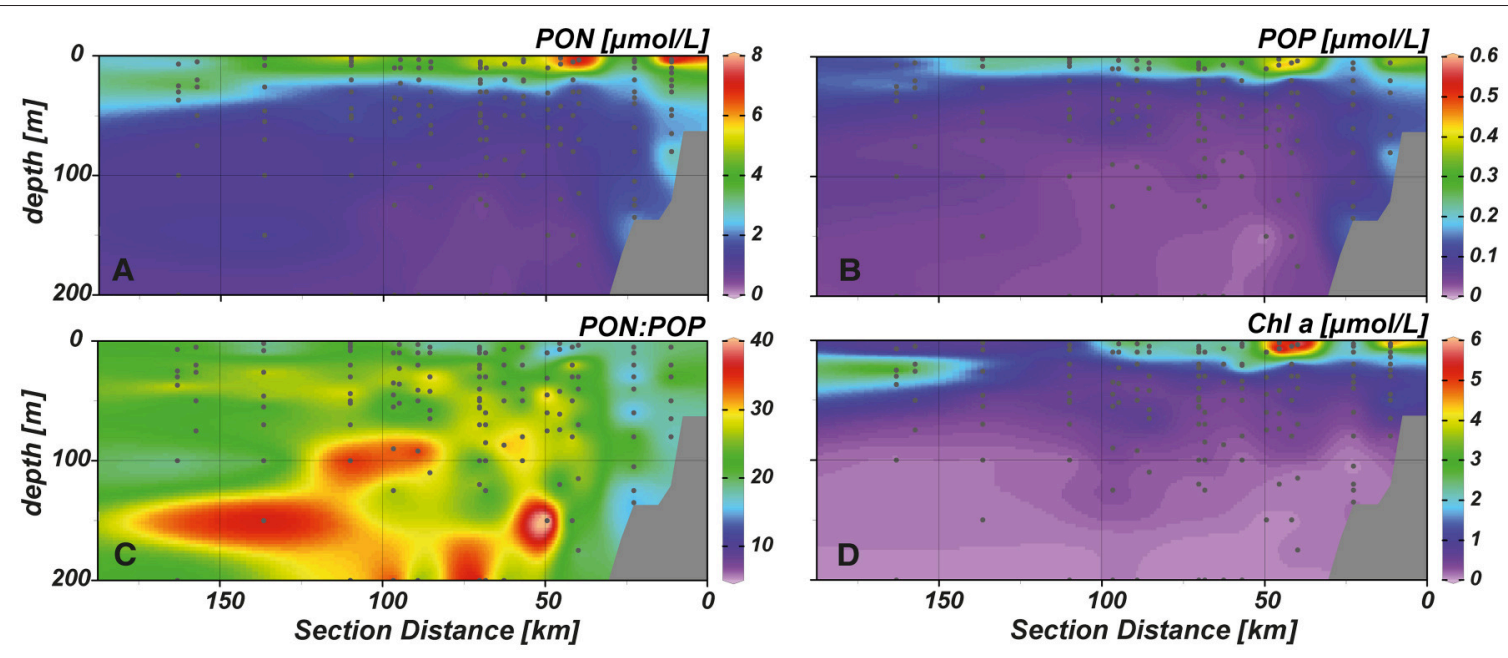

FIGURE 4 | Spatial distribution of (A) particulate organic nitrogen (PON), (B) particulate organic phosphorus (POP), (C) PON:POP, and (D) chlorophyll a (Chl a) in our study area.
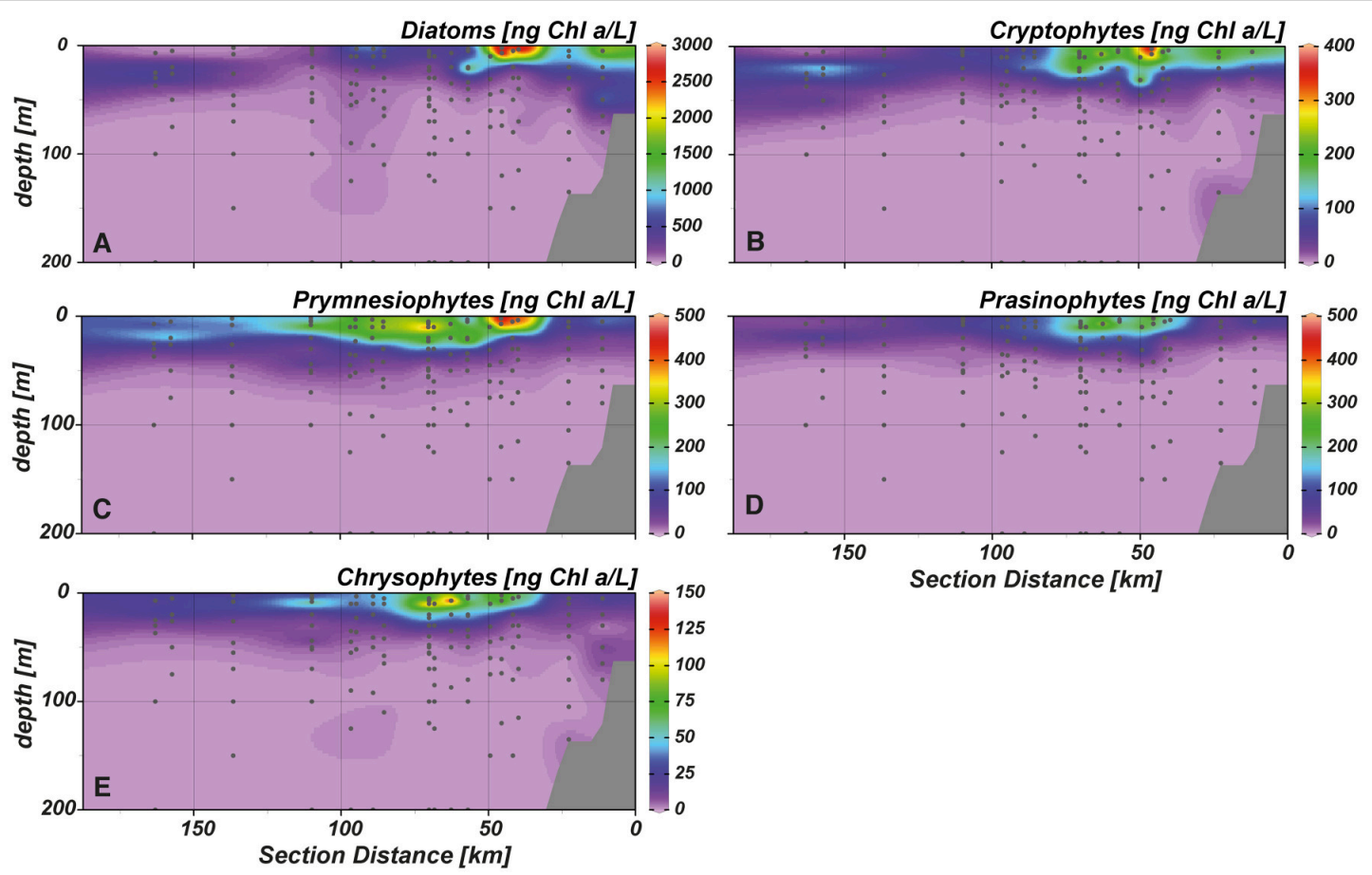

(E) chrysophytes.

20-30 $\mathrm{m}$ above the continental slope. In terms of Chl $a$ biomass, diatoms were again the dominant phytoplankton group, but also prymnesiophytes, prasinophytes, chrysophytes (Figure 5E) and the cyanobacteria Synechococcus (Figure 6A) reached their highest abundances in these areas. At stations further offshore, nutrients were depleted in the surface and prymnesiophytes and Synechococcus dominated the algae community. At the same stations, a deep-chlorophyll maximum was observed between 30 and $50 \mathrm{~m}$ depth and diatoms and cryptophytes were highly abundant. Associated to this offshore deep chlorophyll maximum was also the highest abundance of the cyanobacterium Prochlorococcus in the study area (Figure 6B). This algae group was generally observed at subsurface low-oxygen waters between 30 and $80 \mathrm{~m}$ depth. Abundances of other phytoplankton classes such as dinoflagellates and chlorophytes were negligible in our study area and are therefore not shown. 


\section{Abundance of Diazotrophic Cyanobacteria and $\mathrm{N}_{2}$ Fixation Rate Measurements}

Aside from pigments indicative for the abundance of Prochlorococcus and Synechococcus, evidence for the occurrence of other-possibly diazotrophic-cyanobacteria was found in the study area. Colonial cyanobacteria, distinguished by their marker pigment myxoxanthophyll, were present in the surface layer of the near shore and shelf stations (Figure 7A). Lower abundances were observed close to the surface at outer shelf stations and in the deep chlorophyll maximum at the offshore stations. Diazotrophic cyanobacteria, represented by the accessory pigments aphanizophyll, were most abundant in the upper $40 \mathrm{~m}$ at the near shore stations but also showed higher abundances in surface waters of the shelf and above the continental slope (Figure 7B).

Active $\mathrm{N}_{2}$ fixation was detected almost throughout the entire water column in the study area. However, rates were generally below $1 \mathrm{nmol} \mathrm{d}^{-1} \mathrm{~L}^{-1}$. Highest $\mathrm{N}_{2}$ fixation rates $\left(2-5 \mathrm{nmol} \mathrm{d}^{-1} \mathrm{~L}^{-1}\right)$ were detected on the shelf in the upper $40 \mathrm{~m}$ of the water column, where high rates of $\mathrm{N}_{2}$ fixation coincided with the abundance of diazotrophic marker pigments (Figure 8).

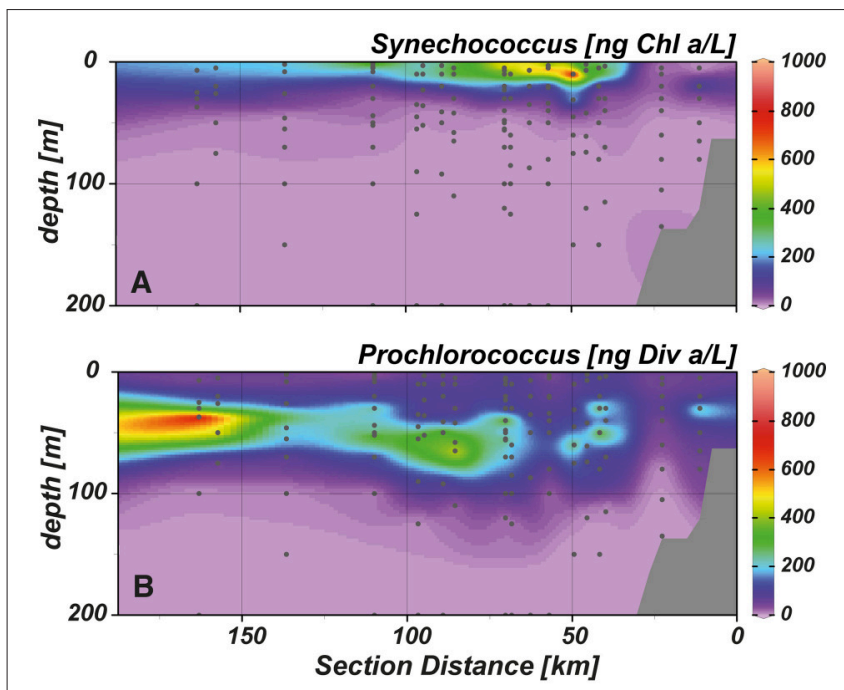

FIGURE 6 | Cross-shelf transects showing the distribution of the cyanobacteria (A) Synechococcus and (B) Prochlorococcus.

\section{DISCUSSION}

\section{Phytoplankton Succession and Particulate Organic Matter Stoichiometry}

Upwelling and the associated supply of nutrients to the surface ocean fuelled high primary production in the ETSP for the duration of our cruise in austral summer 2012. The near shore and shelf $\mathrm{Chl} a$ maximum was dominated by diatoms, which is characteristic for the Peruvian upwelling system (Chavez et al., 1996; Pennington et al., 2006; Franz et al., 2012b). Due to their high growth rate (Sarthou et al., 2005) and nutrient storage capacity (Raven, 1997) diatoms outcompete other algae groups when nutrients are abundant. Over the continental slope, mixtures of different phytoplankton groups were present, consisting of diatoms, prymnesiophytes, prasinophytes, and chrysophytes. As waters were transported offshore, silicate was depleted in the surface ocean, and the phytoplankton assemblage changed from a diatom dominated community to an assemblage of non-siliceous phytoplankton groups, where prymnesiophytes and the cyanobacterium Synechococcus prevailed. In subsurface waters, elevated PON:POP ratios $(\sim 30: 1)$ coincided with a high abundance of Prochlorococcus, which are known to exhibit higher than Redfield N:P ratios due to their slow growth rates (Bertilsson et al., 2003; Biller et al., 2015). Presence of this picophytoplankton group extended below the oxycline and prevailed throughout the study area. Low light adapted Prochlorococcus strains have been identified in different OMZs (Goericke et al., 2000; Beman and Carolan, 2013) including the ETSP (Ras et al., 2008; Lavin et al., 2010). Due to their small size and unique pigment composition

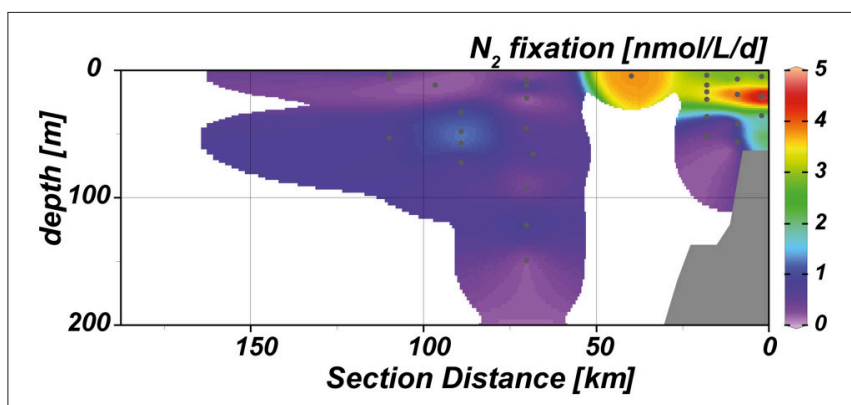

FIGURE 8 | Cross-shelf transect of measured $\mathrm{N}_{2}$ fixation rates.
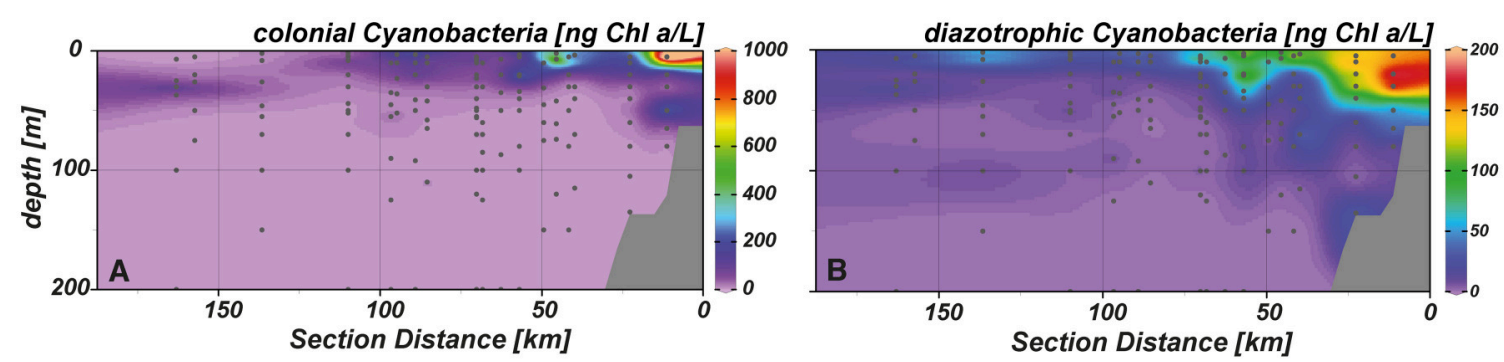

FIGURE 7 | Spatial distribution of (A) colonial and (B) diazotrophic cyanobacteria in our study area. 
they are highly adapted to low light levels (Moore et al., 1998) and thus can make use of the higher nutrient load available at depth.

A distinct succession of phytoplankton species from onshore to offshore has previously been recognized in the Peruvian upwelling system (Franz et al., 2012b). This study reported that very low inorganic $\mathrm{N}: \mathrm{P}$ ratios in the water column directly translated into low cellular $\mathrm{N}: \mathrm{P}$ ratios in the microorganisms. The authors argued that there is a linear relationship between available and cellular $\mathrm{N}: \mathrm{P}$ ratios and that low nutrient stoichiometries in the water column selected for certain algae groups with lower cellular N:P quotas, supporting the hypothesis of Arrigo (2005), Klausmeier et al. (2004b), and Sterner and Elser (2002). Non-Redfield nutrient utilization by these organisms consumed the excess $\mathrm{P}$ in the water column and thereby restored the stoichiometry of inorganic nutrients back to Redfield proportions as waters were transported offshore.

During our study, a pronounced surplus of $\mathrm{P}$ over $\mathrm{N}$ was measured in waters that were transported to the surface by upwelling, a consequence of $\mathrm{N}$-loss processes within the Peruvian OMZ (Dalsgaard et al., 2012; Kalvelage et al., 2013) and high concentrations of $\mathrm{P}$, which were released from the sediment under reducing conditions (cf Figure 3B). However, despite very low inorganic $\mathrm{N}: \mathrm{P}$ ratios of $2.5-10$ at the inner shelf stations and the surface layer further offshore, PON:POP ratios in these areas were close to or even above Redfield proportions, with no indication of non-Redfield nutrient uptake. At the same time, high $P^{*}$-values declined relatively fast as waters were transported to the surface and away from the coast and $\mathrm{N}: \mathrm{P}$ draw down ratios were low, which conflicts with the apparent absence of non-Redfield production.

The observed deviation of PON:POP ratios from inorganic nutrient stoichiometries, accompanied by decreasing $P^{*}$ values, can be explained by different mechanisms: (1) non-Redfield nutrient assimilation reduced $\mathrm{P}^{*}$, while the surplus of phosphorus in the biomass was released as DOP, (2) the particulate organic matter pool had a large detrital component which was enriched in $\mathrm{N}$ relative to $\mathrm{P}$, resulting in higher PON:POP ratios and/or (3) nutrient assimilation was according to Redfield and excess phosphate in the water column was reduced by $\mathrm{N}_{2}$ fixation.

\section{Non-Redfield Nutrient Assimilation}

Theoretical and experimental approaches showed that the availability and stoichiometry of nutrients in seawater can induce differences in cellular composition of phytoplankton (Geider and La Roche, 2002; Moore et al., 2008, 2013; Mills and Arrigo, 2010; Franz et al., 2012a). Low inorganic nutrient supply ratios, decreasing $P^{*}$-values and low concentrations of both nitrate and phosphate in the surface ocean indicates that nutrients were assimilated in non-Redfield proportions during the time of our study. We suggest that the surplus of phosphorus in the biomass was transferred from the particulate into the dissolved organic phosphorus pool, confirmed by the presence of elevated DOP concentrations in the surface close to shore. Unlike the other nutrients, DOP is low in the OMZ relative to the surface layer. As other DOP sources (such as river discharge) do not exist in the study area, DOP is likely to originate from surface layer production. "Luxury" $\mathrm{P}$ uptake and subsequent DOP release under $\mathrm{P}$ replete conditions has been previously observed in mesocosm experiments (Ruttenberg and Dyhrman, 2012; Meyer et al., 2016). Mackey et al. (2012) argued that this channeling of $P$ into DOP might be an important part of the $\mathrm{P}$ cycle in upwelling regions. Instead of $\mathrm{P}$ being transported out of the euphotic zone by export production, it is retained and remains available for phytoplankton.

Non-Redfield production might have further been masked by remineralization of phosphorus from particulate organic matter (POM), which has been observed to strongly impact nutrient stoichiometry in other hypoxic areas, where it can account for a flux of 11-27 $\mu \mathrm{mol} \mathrm{P} \mathrm{m}^{-2} \mathrm{~d}^{-1}$ (Jilbert et al., 2011). Large parts of POM in our study area do not appear to be freshly produced, as the surface POC:Chl $a$ ratio is considerably higher ( $>100: 1$; Figure S2) than previously reported for the ETSP upwelling regime ( 50:1; Chavez et al., 1996) or as described for diatom-dominated communities (15:1-75:1; e.g., Sathyendranath et al., 2009; Lorenzoni et al., 2015). This implies that the POM we encountered had a large detrital component. As organic phosphorus is known to be remineralized more rapidly than carbon and nitrogen (Loh and Bauer, 2000; Kolowith et al., 2001; Burkhardt et al., 2014), elevated PON:POP ratios seem be the result of selective degradation of POP.

\section{Co-occurrence of $\mathrm{P}^{*}$ Consumption, Diazotroph Abundance and $\mathbf{N}_{\mathbf{2}}$ Fixation}

It has previously been shown that certain phytoplankton communities and/or species do not adjust their internal stoichiometries to match low nutrient ratios in the surrounding medium (Hall et al., 2005; Meyer et al., 2016). Other studies suggest that phytoplankton nutrient assimilation follows their optimal uptake ratio under nutrient replete conditions (Klausmeier et al., 2004a) and is more dependent on the growth rate of individual species and algae communities (Goldman et al., 1979; Hillebrand et al., 2013) than on the initial nutrient supply ratio. Thus, PON:POP ratios close to or higher than Redfield proportions during our research cruise might also be explained by phytoplankton utilizing nutrients in Redfield proportions. As an excess of phosphate over nitrate and/or high concentrations of DOP are thought to create a niche for diazotrophic organisms (Björkman and Karl, 2003; Sohm and Capone, 2006; Deutsch et al., 2007; Mahaffey et al., 2014), P* might have been consumed by $\mathrm{N}_{2}$ fixers. Indeed, we observed highest abundances of diazotrophs and highest $\mathrm{N}_{2}$ fixation rates in areas where we measured elevated DOP and $\mathrm{P}^{*}$ concentrations. An average of 25-650 $\mu \mathrm{mol} \mathrm{N} \mathrm{m}{ }^{-2} \mathrm{~d}^{-1}$ has been determined for $\mathrm{N}_{2}$ fixation in that area (Löscher et al., 2016). Assuming a lower border for P uptake at Redfield conditions, an approximate uptake of $40 \mu \mathrm{mol}$ $\mathrm{P} \mathrm{m}{ }^{-2} \mathrm{~d}^{-1}$ through $\mathrm{N}_{2}$ fixation would be required. Lomnitz et al. (2016) determined a P flux of $1.04 \pm 0.31 \mathrm{mmol} \mathrm{m}^{-2} \mathrm{~d}^{-1}$ from the sediment to the water column, which is $2-3$ orders of magnitude higher than what could be removed by $\mathrm{N}_{2}$ fixation. Thus, $\mathrm{N}_{2}$ fixation indeed contributes to the removal of $\mathrm{P}^{*}$ from the water column, however, additional processes are required. 
Especially colonial cyanobacteria, represented by the marker pigment aphanizophyll, were widely present in surface waters of near shore and shelf stations and also occurred at stations further offshore. Aphanizophyll is a pigment that has been found in heterocyst forming diazotrophs like Aphanizomenon spp. and Anabaena spp., which live in brackish or estuarine waters (Hertzberg and Liaaen-Jensen, 1971). Although it has also been found in the non-diazotrophic freshwater species Microcystis aeruginosa (Hertzberg and Liaaen-Jensen, 1971), the pigment is generally indicative for $\mathrm{N}_{2}$ fixing cyanobacteria in freshwater systems (Donald et al., 2013; Louda et al., 2015 and references therein). In the oceanic environment, reports of the detection of aphanizophyll are extremely scarce. It has, however, been detected after the decline of a diatom bloom in mesoscosm experiments off Peru (Hauss et al., 2012) and during an experiment in the eastern tropical North Atlantic (Czerny et al., 2016). In both cases the pigment was attributed to the existence of $\mathrm{N}_{2}$ fixing cyanobacteria.

At the near shore and shelf stations, we also detected high abundances of colonial cyanobacteria, indicated by the marker pigment myxoxanthophyll. This carotenoid can be found in marine $\mathrm{N}_{2}$ fixing cyanobacteria (Carpenter et al., 1993; Schluter et al., 2004; Franz et al., 2012b), but is regarded a general marker for colonial cyanobacteria in freshwater environments, where it can also be found in non-diazotrophic cyanobacteria (Louda et al., 2015). The co-occurrence of cyanobacterial pigment abundances and highest $\mathrm{N}_{2}$ fixation rates suggests that myxoxanthophyll and aphanizophyll may indeed be indicative of diazotrophs in the ETSP. Thus, pigment-based chemotaxonomy appears to be a valuable, but understudied tool to determine the distribution of diazotrophs in seawater.

Although $\mathrm{N}_{2}$ fixation was already suggested to take place in the vicinity of upwelling regions (Karl and Letelier, 2008) and in close spatial coupling to denitrification (Deutsch et al., 2007), the existence of diazotrophic cyanobacteria in nutrient replete surface waters of upwelling regions is counterintuitive when considering the classical paradigm that high concentrations of reactive nitrogen compounds inhibit diazotrophy (Tyrrell, 1999; Ward et al., 2013). However, there is growing evidence that $\mathrm{N}_{2}$ fixation occurs under $\mathrm{N}$-rich conditions (Fernandez et al., 2011; Knapp, 2012; Knapp et al., 2012; Dekaezemacker et al., 2013; Meyer et al., 2016) and even within upwelling regions of the Benguela and equatorial Atlantic (Sohm et al., 2011; Subramaniam et al., 2013). An explanation based on the genetic regulation of certain diazotrophs has just been provided by Bombar et al. (2016). In the Peruvian upwelling region, the high supply of iron and phosphate from the sediment seems to stimulate growth of diazotrophs, thereby allowing them to coexist with a $\mathrm{NO}_{3}^{-}$-supported diatom bloom. Further offshore, diminished iron availability limits algal growth (Hutchins et al., 2002), consequently also restricting the growth of diazotrophs.

\section{CONCLUSION}

During a research expedition to the Humboldt Current system in austral summer 2012, we investigated the phytoplankton community composition and response to low $\mathrm{N}: \mathrm{P}$ ratios in water masses influenced by the Peruvian OMZ. Our study confirmed that a variety of phytoplankton species coexist in this dynamic ecosystem. A considerable portion of excess phosphorus in the surface was reduced as water masses were transported away from the shore. The data presented here suggest that there are several mechanisms responsible for $\mathrm{P}^{*}$ removal in the ETSP. While non-Redfield nutrient utilization as one of the mechanisms could not be ruled out, there is evidence for the depletion of $\mathrm{P}^{*}$ through diazotrophic $\mathrm{N}_{2}$ fixation. The recent discovery of novel Trichodesmium phylotypes (Turk-Kubo et al., 2014) and other unknown diazotrophs (Sohm et al., 2011) in upwelling regions of the ETSP and Benguela and our observations of previously undetected cyanobacterial marker pigments along with $\mathrm{N}_{2}$ fixation in the Peruvian upwelling region add to the growing body of evidence that there are still unknown communities of autotrophic and heterotrophic diazotrophs (Bonnet et al., 2013; Loescher et al., 2014) that exist in environments previously not considered favoring $\mathrm{N}_{2}$ fixation. Uncertainties concerning the identity and activity of diazotrophs in the Peruvian upwelling regions need to be addressed in future studies in order to elucidate sensitivities and constraints of $\mathrm{N}_{2}$ fixation in the ocean.

\section{AUTHOR CONTRIBUTIONS}

JM and UR designed the study. JM, CL, and GL collected samples onboard. JM analyzed DOM, POM, HPLC, and Chl a. CL measured and analyzed N2 fixation rates. GL provided nutrient and CTD data. JM wrote the manuscript with UR, CL, and GL.

\section{ACKNOWLEDGMENTS}

The authors thank the authorities of Peru for permission to work in their territorial waters. We thank the chief scientists, captain and crew of $\mathrm{R} / \mathrm{V}$ Meteor for their support during the cruise. We acknowledge Anna Reichel for her great support during the cruise and in the laboratory. We thank Gabriele Klockgether for nutrient measurements and Helena Hauss and Scarlett Sett for critically commenting on an earlier version of the manuscript. The manuscript also benefitted from comments and suggestions of the two reviewers. This work is a contribution of the Collaborative Research Center (SFB 754) "ClimateBiogeochemistry Interactions in the Tropical Ocean" (www. sfb754.de), funded by the Deutsche Forschungsgemeinschaft (DFG). Additional funding was provided by the European Union, H2020 (grant ID \#704274 to CL).

\section{SUPPLEMENTARY MATERIAL}

The Supplementary Material for this article can be found online at: http://journal.frontiersin.org/article/10.3389/fmars. 2017.00001/full\#supplementary-material

Figure S1 | Cross-shelf transect showing the interpolated concentration of biogenic silica (BSi).

Figure S2 | Particulate organic carbon (POC in $\mu \mathrm{g} / \mathrm{L}$ ) to chlorophyll a (Chl a in $\mu \mathrm{g} / \mathrm{L}$ ) ratios in the upper $200 \mathrm{~m}$ of the eastern tropical South Pacific. 


\section{REFERENCES}

Arrigo, K. R. (2005). Marine microorganisms and global nutrient cycles. Nature 437, 349-355. doi: 10.1038/nature04159

Barlow, R. G., Cummings, D. G., and Gibb, S. W. (1997). Improved resolution of mono- and divinyl chlorophylls a and b and zeaxanthin and lutein in phytoplankton extracts using reverse phase C-8 HPLC. Mar. Ecol. Prog. Ser. 161, 303-307. doi: 10.3354/meps161303

Beman, J. M., and Carolan, M. T. (2013). Deoxygenation alters bacterial diversity and community composition in the ocean's largest oxygen minimum zone. Nat. Commun. 4, 1-11. doi: 10.1038/ncomms3705

Bertilsson, S., Berglund, O., Karl, D. M., and Chisholm, S. W. (2003). Elemental composition of marine Prochlorococcus and Synechococcus: implications for the ecological stoichiometry of the sea. Limnol. Oceangr. 48, 1721-1731. doi: 10.4319/lo.2003.48.5.1721

Biller, S. J., Berube, P. M., Lindell, D., and Chisholm, S. W. (2015). Prochlorococcus: the structure and function of collective diversity. Nat. Rev. Microbiol. 13, 13-27. doi: 10.1038/nrmicro3378

Björkman, K. M., and Karl, D. M. (2003). Bioavailability of dissolved organic phosphorus in the euphotic zone at Station ALOHA, North Pacific Subtropical Gyre. Limnol. Oceangr. 48, 1049-1057. doi: 10.4319/lo.2003.48.3.1049

Bombar, D., Paerl, R. W., and Riemann, L. (2016). Marine non-cyanobacterial diazotrophs: moving beyond molecular detection. Trends Microbiol. 24, 916-927. doi: 10.1016/j.tim.2016.07.002

Bonnet, S., Dekaezemacker, J., Turk-Kubo, K. A., Moutin, T., Hamersley, R. M., Grosso, O., et al. (2013). Aphotic N2 fixation in the eastern tropical South Pacific Ocean. PLoS ONE 8:e81265. doi: 10.1371/journal.pone.0081265

Burkhardt, B. G., Watkins-Brandt, K. S., Defforey, D., Paytan, A., and White, A. E. (2014). Remineralization of phytoplankton-derived organic matter by natural populations of heterotrophic bacteria. Mar. Chem. 163, 1-9. doi: 10.1016/j.marchem.2014.03.007

Carpenter, E. J., Oneil, J. M., Dawson, R., Capone, D. G., Siddiqui, P., Roenneberg, T., et al. (1993). The tropical diazotrophic phytoplankter Trichodesmium: biological characteristics of 2 common species. Mar. Ecol. Prog. Ser. 95, 295-304. doi: 10.3354/meps095295

Chavez, F. P., Buck, K. R., Service, S. K., and Newton, J. (1996). Phytoplankton variability in the central and eastern tropical Pacific. Deep Sea Res. II 43, 835-870. doi: 10.1016/0967-0645(96)00028-8

Czerny, J., Hauss, H., Löscher, C. R., and Riebesell, U. (2016). Dissolved N:P ratio changes in the eastern tropical North Atlantic: effect on phytoplankton growth and community structure. Mar. Ecol. Prog. Ser. 545, 49-62. doi: $10.3354 /$ meps 11600

Dalsgaard, T., Thamdrup, B., Farías, L., and Revsbech, P. N. (2012). Anammox and denitrification in the oxygen minimum zone of the eastern South Pacific. Limnol. Oceangr. 57, 1331-1346. doi: 10.4319/lo.2012.57.5.1331

Dekaezemacker, J., Bonnet, S., Grosso, O., Moutin, T., Bressac, M., and Capone, D. G. (2013). Evidence of active dinitrogen fixation in surface waters of the eastern tropical South Pacific during $\mathrm{El} \mathrm{Ni-o}$ and $\mathrm{La} \mathrm{Ni-a}$ events and evaluation of its potential nutrient controls. Glob. Biogeochem. Cycles 27, 768-779. doi: 10.1002/gbc.20063

Deutsch, C., Sarmiento, J. L., Sigman, D. M., Gruber, N., and Dunne, J. P. (2007). Spatial coupling of nitrogen inputs and losses in the ocean. Nature 445, 163-167. doi: 10.1038/nature05392

DiTullio, G. R., Geesey, M. E., and Maucher, J. M. (2005). Influence of iron on algal community composition and physiological status in the Peru upwelling system. Limnol. Oceanogr. 50, 1887-1907. doi: 10.4319/lo.2005.50.6.1887

Donald, D. B., Bogard, M. J., Finlay, K., Bunting, L., and Leavitt, P. R. (2013). Phytoplankton-specific response to enrichment of phosphorus-rich surface waters with ammonium, nitrate, and urea. PLOS ONE 8:e53277. doi: 10.1371/journal.pone.0053277

Dyhrman, S. T., Chappell, P. D., Haley, S. T., Moffett, J. W., Orchard, E. D., Waterbury, J. B., et al. (2006). Phosphonate utilization by the globally important marine diazotroph Trichodesmium. Nature 439, 68-71. doi: 10.1038 /nature 04203

Fernandez, C., Farías, L., and Ulloa, O. (2011). Nitrogen fixation in denitrified marine waters. PLoS ONE 6:e20539. doi: 10.1371/journal.pone.0020539

Fernandez, C., Gonzalez, M. L., Mu-oz, C., Molina, V., and Farías, L. (2015). Temporal and spatial variability of biological nitrogen fixation off the upwelling system of central Chile (35-38.5 S). J. Geophys. Res. Oceans 120, 3330-3349. doi: 10.1002/2014JC010410

Franz, J., Krahmann, G., Lavik, G., Grasse, P., Dittmar, T., and Riebesell, U. (2012b). Dynamics and stoichiometry of nutrients and phytoplankton in the waters influenced by the oxygen minimum zone in the eastern tropical Pacific. Deep Sea Res. I 62, 20-31. doi: 10.1016/j.dsr.2011.12.004

Franz, J. M. S., Hauss, H., Sommer, U., Dittmar, T., and Riebesell, U. (2012a). Production, partitioning and stoichiometry of organic matter under variable nutrient supply during mesocosm experiments in the tropical Pacific and Atlantic Ocean. Biogeosciences 9, 4629-4643. doi: 10.5194/bg-9-4629-2012

Geider, R., and La Roche, J. (2002). Redfield revisited: variability of C:N:P in marine microalgae and its biochemical basis. Eur. J. Phycol. 37, 1-17. doi: $10.1017 / S 0967026201003456$

Gieskes, W. W. C., Kraay, G. W., Nontji, A., Setiapermana, D., and Sutomo (1988). Monsoonal alternation of a mixed and a layered structure in the phytoplankton of the euphotic zone of the banda sea (Indonesia): a mathematical analysis of algal pigment fingerprints. Neth. J. Sea Res. 22, 123-137. doi: 10.1016/0077-7579(88)90016-6

Goericke, R., Olson, R. J., and Shalapyonok, A. (2000). A novel niche for Prochlorococcus sp. in low-light suboxic environments in the Arabian Sea and the Eastern Tropical North Pacific. Deep Sea Res. I 47, 1183-1205. doi: 10.1016/S0967-0637(99)00108-9

Goering, J. J. (1968). Denitrification in the oxygen minimum layer of the eastern tropical Pacific Ocean. Deep Sea Res. Oceanogr. Abstr. 15, 157-164. doi: 10.1016/0011-7471(68)90037-5

Goldman, J. C., McCarthy, J. J., and Peavey, D. G. (1979). Growth-rate influence on the chemical composition of phytoplankton in oceanic waters. Nature 279, 210-215. doi: 10.1038/279210a0

Grasshoff, K., Kremling, K., and Ehrhardt, M. (1999). "Determination of nutrients," in Methods of Seawater Analysis, 3rd Edn., eds K. Grasshoff, K. Kremling, and M. Ehrhardt (Weinheim: Wiley-VCH Verlag GmbH), 159-228.

Greisberger, S., and Teubner, K. (2007). Does pigment composition reflect phytoplankton community structure in differing temperature and light conditions in a deep alpine lake? An approach using HPLC and delayed fluorescence techniques. J. Phycol. 43, 1108-1119. doi: $10.1111 / j .1529-8817.2007 .00404 . x$

Hall, S. R., Smith, V. H., Lytle, D. A., and Leibold, M. A. (2005). Constraints on primary producer N:P stoichiometry along N:P supply ratio gradients. Ecology 86, 1894-1904. doi: 10.1890/04-1045

Hamersley, M. R., Lavik, G., Woebken, D., Rattray, J. E., Lam, P., Hopmans, E. C., et al. (2007). Anaerobic ammonium oxidation in the Peruvian oxygen minimum zone. Limnol. Oceangr. 52, 923-933. doi: 10.4319/lo.2007.52.3.0923

Hansen, H. P., and Koroleff, F. (1999). "Determination of nutrients," in Methods of Seawater Analysis, eds K. Kremling and M. Ehrhardt (Weinheim: Wiley-VCH Verlag GmbH), 159-228.

Hauss, H., Franz, J. M. S., and Sommer, U. (2012). Changes in N:P stoichiometry influence taxonomic composition and nutritional quality of phytoplankton in the Peruvian upwelling. J. Sea Res. 73, 74-85. doi: 10.1016/j.seares.2012.06.010

Hertzberg, S., and Liaaen-Jensen, S. (1971). The constitution of aphanizophyll. Phytochemistry 10, 3251-3252. doi: 10.1016/S0031-9422(00)97381-3

Hertzberg, S., Liaaen-Jensen, S., and Siegelman, H. W. (1971). The carotenoids of blue-green algae. Phytochemistry 10, 3121-3127. doi: 10.1016/S0031-9422(00)97362-X

Hillebrand, H., Steinert, G., Boersma, M., Malzahn, A., Meunier, C. L., Plum, C., et al. (2013). Goldman revisited: faster-growing phytoplankton has lower $\mathrm{N}$ : P and lower stoichiometric flexibility. Limnol. Oceangr. 58, 2076-2088. doi: 10.4319/lo.2013.58.6.2076

Hutchins, D. A., Hare, C. E., Weaver, R. S., Zhang, Y., Firme, G. F., DiTullio, G. R., et al. (2002). Phytoplankton iron limitation in the Humboldt Current and Peru Upwelling. Limnol. Oceangr. 47, 1-15. doi: 10.4319/lo.2002.47. 4.0997

Ingall, E., and Jahnke, R. (1994). Evidence for enhanced phosphorus regeneration from marine sediments overlain by oxygen depleted waters. Geochim. Cosmochim. Acta 58, 2571-2575. doi: 10.1016/0016-7037(94)90033-7

Jeffrey, S. W., Wright, S. W., Wright, S. W., Zapata, M., and Zapata, M. (2011). "Microalgal classes and their signature pigments," in Phytoplankton Pigments, eds S. Roy, C. Llewellyn, E. S. Egeland, and G. Johnsen (Cambridge: Cambridge University Press), 3-77. 
Jilbert, T., Slomp, C. P., Gustafsson, B. G., and Boer, W. (2011). Beyond the Fe-Predox connection: preferential regeneration of phosphorus from organic matter as a key control on Baltic Sea nutrient cycles. Biogeosciences 8, 1699-1720. doi: 10.5194/bg-8-1699-2011

Kalvelage, T., Lavik, G., Lam, P., Contreras, S., Arteaga, L., Löscher, C. R., et al. (2013). Nitrogen cycling driven by organic matter export in the South Pacific oxygen minimum zone. Nat. Geosci. 6, 228-234. doi: 10.1038/ngeo1739

Karl, D. M., and Letelier, R. M. (2008). Nitrogen fixation-enhanced carbon sequestration in low nitrate, low chlorophyll seascapes. Mar. Ecol. Prog. Ser. 364, 257-268. doi: 10.3354/meps07547

Klausmeier, C. A., Litchman, E., Daufresne, T., and Levin, S. A. (2004b). Optimal nitrogen-to-phosphorus stoichiometry of phytoplankton. Nature 429, 171-174. doi: 10.1038/nature02454

Klausmeier, C. A., Litchman, E., and Levin, S. A. (2004a). Phytoplankton growth and stoichiometry under multiple nutrient limitation. Limnol. Oceangr. 49, 1463-1470. doi: 10.4319/lo.2004.49.4_part_2.1463

Knapp, A. N. (2012). The sensitivity of marine $\mathrm{N}_{2}$ fixation to dissolved inorganic nitrogen. Front. Microbiol. 3:374. doi: 10.3389/fmicb.2012.00374

Knapp, A. N., Dekaezemacker, J., Bonnet, S., Sohm, J. A., and Capone, D. G. (2012). Sensitivity of Trichodesmium erythraeum and Crocosphaera watsonii abundance and $\mathrm{N}_{2}$ fixation rates to varying $\mathrm{NO}_{3}^{-}$and $\mathrm{PO}_{4}^{3-}$ concentrations in batch cultures. Aquat. Microb. Ecol. 66, 223-236. doi: 10.3354/ame01577

Kolowith, L. C., Ingall, E. D., and Benner, R. (2001). Composition and cycling of marine organic phosphorus. Limnol. Oceangr. 46, 309-320. doi: 10.4319/lo.2001.46.2.0309

Lavin, P., González, B., Santibá-ez, J. F., Scanlan, D. J., and Ulloa, O. (2010). Novel lineages of Prochlorococcus thrive within the oxygen minimum zone of the eastern tropical South Pacific. Environ. Microbiol. Rep. 2, 728-738. doi: 10.1111/j.1758-2229.2010.00167.x

Loescher, C. R., Großkopf, T., Desai, F. D., Gill, D., Schunck, H., Croot, P. L., et al. (2014). Facets of diazotrophy in the oxygen minimum zone waters off Peru. ISME J. 8, 2180-2192. doi: 10.1038/ismej.2014.71

Loh, A. N., and Bauer, J. E. (2000). Distribution, partitioning and fluxes of dissolved and particulate organic C, N and P in the eastern North Pacific and Southern Oceans. Deep Sea Res. I 47, 2287-2316. doi: 10.1016/S0967-0637(00) 00027-3

Lomnitz, U., Sommer, S., Dale, A. W., Löscher, C. R., Noffke, A., Wallmann, K., et al. (2016). Benthic phosphorus cycling in the Peruvian oxygen minimum zone. Biogeosciences 13, 1367-1386. doi: 10.5194/bg-13-1367-2016

Lorenzoni, L., Toro-Farmer, G., Varela, R., Guzman, L., Rojas, J., Montes, E., et al. (2015). Characterization of phytoplankton variability in the Cariaco Basin using spectral absorption, taxonomic and pigment data. Remote Sens. Environ. 167, 259-268. doi: 10.1016/j.rse.2015.05.002

Löscher, C. R., Bange, H. W., Schmitz, R. A., Callbeck, C. M., Engel, A., Hauss, H., et al. (2016). Water column biogeochemistry of oxygen minimum zones in the eastern tropical North Atlantic and eastern tropical South Pacific oceans. Biogeosciences 13, 3585-3606. doi: 10.5194/bg-13-3585-2016

Louda, J., Grant, C., Browne, J., and Hagerthey, S. (2015). "Pigment-based chemotaxonomy and its application to everglades periphyton," in Microbiology of the Everglades Ecosystem, eds J. A. Entry, A. D. Gottlieb, K. Jayachandran, and A. Ogram (Boca Raton, FL: CRC Press), 289-349.

Mackey, D. J., Higgins, H. W., and Mackey, M. D. (1998). Algal class abundances in the western equatorial Pacific: estimation from HPLC measurements of chloroplast pigments using CHEMTAX. Deep Sea Res. I 45, 1441-1468. doi: 10.1016/s0967-0637(98)00025-9

Mackey, K. R. M., Mioni, C. E., Ryan, J. P., and Paytan, A. (2012). Phosphorus cycling in the red tide incubator region of Monterey Bay in response to upwelling. Front. Microbiol. 3:33. doi: 10.3389/fmicb.2012.00033

Mackey, M. D., Mackey, D. J., and Higgins, H. W. (1996). CHEMTAX-a program for estimating class abundances from chemical markers: application to HPLC measurements of phytoplankton. Mar. Ecol. Prog. Ser. 144, 265-283. doi: 10.3354/meps144265

Mahaffey, C., Reynolds, S., and Davis, C. E. (2014). Alkaline phosphatase activity in the subtropical ocean: insights from nutrient, dust and trace metal addition experiments. Front. Microbiol. 1:73. doi: 10.3389/fmars.2014.00073

Meyer, J., Löscher, C. R., Neulinger, S. C., Reichel, A. F., Loginova, A., Borchard, C., et al. (2016). Changing nutrient stoichiometry affects phytoplankton production, DOP accumulation and dinitrogen fixation - a mesocosm experiment in the eastern tropical North Atlantic. Biogeosciences 13, 781-794. doi: 10.5194/bg-13-781-2016

Mills, M. M., and Arrigo, K. R. (2010). Magnitude of oceanic nitrogen fixation influenced by the nutrient uptake ratio of phytoplankton. Nat. Geosci. 3, 412-416. doi: 10.1038/ngeo856

Mohr, W., Großkopf, T., Wallace, D. W. R., and LaRoche, J. (2010). Methodological underestimation of oceanic nitrogen fixation rates. PLoS ONE 5:e12583. doi: 10.1371/journal.pone.0012583

Moore, C. M., Mills, M. M., Arrigo, K. R., Berman-Frank, I., Bopp, L., Boyd, P. W., et al. (2013). Processes and patterns of oceanic nutrient limitation. Nat. Geosci. 6, 701-710. doi: 10.1038/ngeo1765

Moore, C. M., Mills, M. M., Langlois, R., Milne, A., Achterberg, E. P., La Roche, J., et al. (2008). Relative influence of nitrogen and phosphorous availability on phytoplankton physiology and productivity in the oligotrophic sub-tropical North Atlantic Ocean. Limnol. Oceangr. 53, 291-305. doi: 10.4319/lo.2008.53.1.0291

Moore, L. R., Rocap, G., and Chisholm, S. W. (1998). Physiology and molecular phylogeny of coexisting Prochlorococcus ecotypes. Nature 393, 464-467. doi: $10.1038 / 30965$

Noffke, A., Hensen, C., Sommer, S., Scholz, F., Bohlen, L., Mosch, T., et al. (2012). Benthic iron and phosphorus fluxes across the Peruvian oxygen minimum zone. Limnol. Oceangr. 57, 851-867. doi: 10.4319/lo.2012.57.3.0851

Parsons, T. R., Maita, Y., and Lalli, C. M. (1984). A Manual of Chemical and Biological Methods for Seawater Analysis. Pergamon: Oxford.

Pennington, J. T., Mahoney, K. L., Kuwahara, V. S., Kolber, D. D., Calienes, R., and Chavez, F. P. (2006). Primary production in the eastern tropical Pacific: a review. Progr. Oceanog. 69, 285-317. doi: 10.1016/j.pocean.2006.03.012

Quigg, A., Finkel, Z. V., Irwin, A. J., Rosenthal, Y., Ho, T.-Y., Reinfelder, J. R., et al. (2003). The evolutionary inheritance of elemental stoichiometry in marine phytoplankton. Nature 425, 291-294. doi: 10.1038/nature01953

Ras, J., Claustre, H., and Uitz, J. (2008). Spatial variability of phytoplankton pigment distributions in the Subtropical South Pacific Ocean: comparison between in situ and predicted data. Biogeosciences 5, 353-369. doi: 10.5194/bg-5-353-2008

Raven, J. A. (1997). “The vacuole: A cost-benefit analysis," in The Plant Vacuole, eds R. A. Leigh and D. Sanders (San Diego, CA: Elsevier Ltd.), 59-86.

Redfield, A. C. (1958). The biological control of chemical factors in the environment. Am. Sci. 46, 205-221.

Ruttenberg, K. C., and Dyhrman, S. T. (2012). Dissolved organic phosphorus production during simulated phytoplankton blooms in a coastal upwelling system. Front. Microbiol. 3:274. doi: 10.3389/fmicb.2012.00274

Sarthou, G., Timmermans, K. R., Blain, S., and Tréguer, P. (2005). Growth physiology and fate of diatoms in the ocean: a review. J. Sea Res. 53, 25-42. doi: 10.1016/j.seares.2004.01.007

Sathyendranath, S., Stuart, V., Nair, A., Oka, K., Nakane, T., Bouman, H., et al (2009). Carbon-to-chlorophyll ratio and growth rate of phytoplankton in the sea. Mar. Ecol. Prog. Ser. 383, 73-84. doi: 10.3354/meps07998

Schluter, L., Garde, K., and Kaas, H. (2004). Detection of the toxic cyanobacteria by Nodularia spumigena means of a 4-keto-myxoxanthophyll-like pigment in the Baltic Sea. Mar. Ecol. Prog. Ser. 275, 69-78. doi: 10.3354/meps275069

Sohm, J. A., and Capone, D. G. (2006). Phosphorus dynamics of the tropical and subtropical north Atlantic: Trichodesmium spp. versus bulk plankton. Mar. Ecol. Prog. Ser. 317, 21-28. doi: 10.3354/meps317021

Sohm, J. A., Hilton, J. A., Noble, A. E., Zehr, J. P., Saito, M. A., and Webb, E. A. (2011). Nitrogen fixation in the South Atlantic Gyre and the Benguela Upwelling System. Geophys. Res. Lett. 38:L16608. doi: 10.1029/2011GL0 48315

Somes, C. J., and Oschlies, A. (2015). On the influence of "non-Redfield" dissolved organic nutrient dynamics on the spatial distribution of $\mathrm{N}_{2}$ fixation and the size of the marine fixed nitrogen inventory. Glob. Biogeochem. Cycles 29, 973-993. doi: 10.1002/2014GB005050

Sterner, R. W., and Elser, J. J. (2002). Ecological Stoichiometry: The Biology of Elements from Molecules to the Biosphere. Oxfordshire: Princeton University Press.

Strady, E., Pohl, C., Yakushev, E. V., Krüger, S., and Hennings, U. (2008) PUMP-CTD-System for trace metal sampling with a high vertical resolution. A test in the Gotland Basin, Baltic Sea. Chemosphere 70, 1309-1319. doi: 10.1016/j.chemosphere.2007.07.051 
Subramaniam, A., Mahaffey, C., Johns, W., and Mahowald, N. (2013). Equatorial upwelling enhances nitrogen fixation in the Atlantic Ocean. Geophys. Res. Lett. 40, 1766-1771. doi: 10.1002/grl.50250

Thomsen, S., Kanzow, T., Krahmann, G., Greatbatch, R. J., Dengler, M., and Lavik, G. (2016). The formation of a subsurface anticyclonic eddy in the Peru-Chile Undercurrent and its impact on the near-coastal salinity, oxygen, and nutrient distributions. J. Geophys. Res. Oceans 121, 476-501. doi: 10.1002/2015JC010878

Trees, C. C., Clark, D. K., Bidigare, R. R., Ondrusek, M. E., and Mueller, J. L. (2000). Accessory pigments versus chlorophyll a concentrations within the euphotic zone: a ubiquitous relationship. Limnol. Oceangr. 45, 1130-1143. doi: 10.4319/lo.2000.45.5.1130

Turk-Kubo, K. A., Karamchandani, M., Capone, D. G., and Zehr, J. P. (2014). The paradox of marine heterotrophic nitrogen fixation: abundances of heterotrophic diazotrophs do not account for nitrogen fixation rates in the Eastern Tropical South Pacific. Environ. Microbiol. 16, 3095-3114. doi: $10.1111 / 1462-2920.12346$

Tyrrell, T. (1999). The relative influences of nitrogen and phosphorus on oceanic primary production. Nature 400, 525-531. doi: 10.1038/22941
Ward, B. A., Dutkiewicz, S., Moore, C. M., and Follows, M. J. (2013) Iron, phosphorus, and nitrogen supply ratios define the biogeography of nitrogen fixation. Limnol. Oceangr. 58, 2059-2075. doi: 10.4319/lo.2013.58. 6.2059

Wright, S. W. (1991). Improved HPLC method for the analysis of chlorophylls and carotenoids from marine phytoplankton. Mar. Ecol. Prog. Ser. 77, 183-196. doi: $10.3354 /$ meps 077183

Conflict of Interest Statement: The authors declare that the research was conducted in the absence of any commercial or financial relationships that could be construed as a potential conflict of interest.

Copyright (C) 2017 Meyer, Löscher, Lavik and Riebesell. This is an open-access article distributed under the terms of the Creative Commons Attribution License (CC BY). The use, distribution or reproduction in other forums is permitted, provided the original author(s) or licensor are credited and that the original publication in this journal is cited, in accordance with accepted academic practice. No use, distribution or reproduction is permitted which does not comply with these terms. 